\title{
The many effects of carnivores on their prey and their implications for trophic cascades, and ecosystem structure and function
}

\author{
Authors: John Winnie Jr., \& Scott Creel
}

NOTICE: this is the author's version of a work that was accepted for publication in Food Webs. Changes resulting from the publishing process, such as peer review, editing, corrections, structural formatting, and other quality control mechanisms may not be reflected in this document. Changes may have been made to this work since it was submitted for publication. A definitive version was subsequently published in Food Webs, (September 2016) DOI\# 10.1016/i.fooweb.2016.09.002

Winnie, John Jr., and Scott Creel. "The many effects of carnivores on their prey and their implications for trophic cascades, and ecosystem structure and function." Food Webs (September 2016). DOI:https://dx.doi.org/10.1016/j.fooweb.2016.09.002.

Made available through Montana State University's $\underline{\text { ScholarWorks }}$ scholarworks. montana.edu 


\title{
The many effects of carnivores on their prey and their implications for trophic cascades, and ecosystem structure and function
}

\author{
John Winnie Jr. *, Scott Creel \\ Ecology Department, 310 Lewis Hall, Montana State University, Bozeman, MT 59717, United States
}

\begin{abstract}
A B S T R A C T
Despite some controversy, a wide range of research across multiple taxa have established that carnivores strongly influence prey population dynamics both through direct offtake and indirect risk effects. Because of these powerful top-down effects carnivores can influence ecosystems across multiple trophic levels. Here we discuss research addressing carnivore direct- and indirect effects on prey, and how these effects can influence overall ecosystem structure and function.
\end{abstract}

\section{Contents}

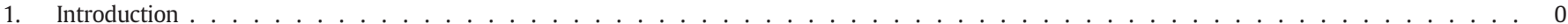

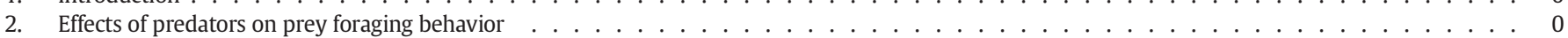

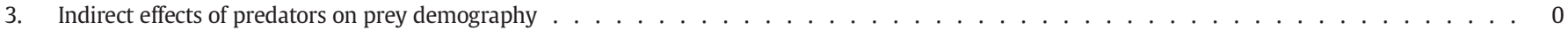

4. Indirect effects of wolves on elk behavior and demography _ . . . . . . . . . . . . . . . . . . . . . . . . . . . . . 0

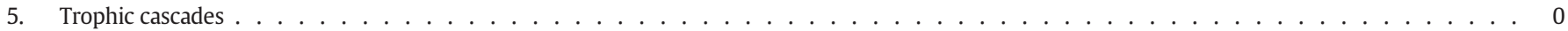

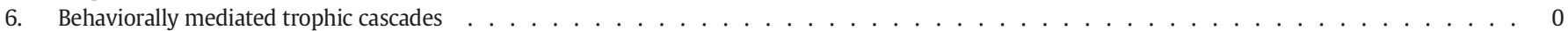

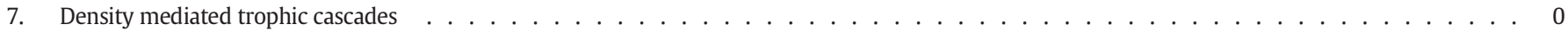

8. Effects of density mediated trophic cascades on ecosystem structure . . . . . . . . . . . . . . . . . . . . . . . . . . 0

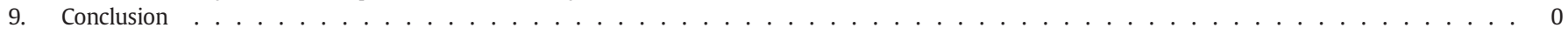

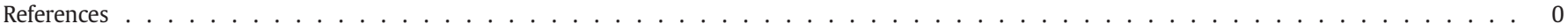

\section{Introduction}

The effects of carnivores on their prey are so profound that despite being nearly undetectable in early Cambrian strata, predators appear to have influenced the evolutionary paths of most taxa around them, likely driving the course of the Cambrian Explosion (Bengtson, 2002; Erwin et al., 2011; Sperling et al., 2013). In ecological time, carnivores most obviously influence prey populations through killing, but some demographic effects are less obvious, and require the observation of prey not killed by predators to detect. Prey survivors are engaging in antipredator behaviors that, at least for the time being, are keeping them alive, reducing their risk of death by predation. Anti-predator behaviors are ubiquitous, with many of the same tactics employed across multiple taxa, and they typically come with costs. The price of these anti- predator behaviors is often paid with decreased foraging time, foraging habitat shifts, and ultimately, decreased reproduction. In systems with sufficient primary productivity to allow for large variation in herbivore density, predator effects (or the lack thereof) on prey demography can fundamentally influence prey's role in the structure and function of ecosystems, with results ranging from stable and diverse, to unpredictable and distorted.

\section{Effects of predators on prey foraging behavior}

Behavioral, ecological and developmental shifts in response to the threat of predation are well documented in aquatic invertebrates and amphibians, as are the costs associated with these shifts. For example, Skelly and Werner (1990) found that tadpoles exposed to caged predators foraged significantly less than tadpoles in the predator-free pools. Overall, tadpoles in pools with high perceived risk had 28\% lower growth rates than those in pools with no risk, and metamorphosed at 
smaller sizes (which typically reduces fecundity in amphibians) than tadpoles in predator-free pools. Similarly, Altweg (2002) found that the presence of caged predators in pools reduced the rate of development in tadpoles, and hindered their ability to developmentally respond to falling water levels. In addition, tadpole survival was lower in pools with high perceived risk, which was attributed to reduced foraging. In many studies of invertebrates, the downstream costs of behavioral and developmental shifts in response to risk include decreased adult survival and decreased reproductive success at maturity (Wells, 1977; Berven and Gill, 1983; Semlitsch, 1985; Semlitsch et al., 1988; Skelly and Werner, 1990).

Prey frequently exchange foraging time for anti-predator behaviors. Vigilance is arguably the most common anti-predator behavior among vertebrates and is often increased at the expense of feeding. Examples of this trade-off include starlings (Sturnus vulgaris) (Jennings and Evans, 1980); ostriches (Struthio camelus) (Bertram, 1980); African ungulates (Underwood, 1982); North American elk (Cervus elaphus) (Winnie and Creel, 2007); and ground squirrels (Spermophilus beldingi) (Bachman, 1993). In invertebrates and tadpoles, foraging activity levels are often reduced in response to the presence of sit-and-wait (ambush) predators, apparently because the probability of encountering a predator declines with decreased prey activity (Scrimgeour et al., 1994a; Altweg, 2002). However, the evidence for systematic differences in responses of vertebrate prey to sit-and-wait and coursing (open-pursuit) predators is limited and mixed (Thaker et al., 2011; Creel et al., 2014).

Prey often shift from preferred foraging habitats into safer, but less profitable habitats when faced with increased predation risk. In classic split-pond experiments Werner et al. (1983) found that in pond halves with predators, small bluegill (Lepomis macrochirus) used near-shore habitats more than small bluegills in pond halves without predators, causing a shift in diet and lower growth rates. Larger bluegills, which were less vulnerable to predation, showed none of these responses (and in fact grew faster due to reduced feeding competition from small bluegills in preferred foraging habitats). Heithaus and Dill (2002) found that bottlenose dolphins (Tursiops aduncus) shifted from shallow, high productivity foraging areas to deeper, less profitable foraging areas during times when tiger sharks (Galiocerdo cuvier) were present in Shark Bay, Australia. Elk in the northwest corner of the Yellowstone ecosystem shifted from foraging in preferred, open grassy habitats when wolves were absent from a drainage, to foraging in less profitable forested habitat when wolves were present in the drainage (Creel et al., 2005). This shift in habitat use came with a corresponding diet shift from preferred grasses to more woody browse, and a decrease in the quantity of food ingested (Christianson and Creel, 2008). In response to the threat of predation from barn owls (Tyto alba), desert gerbils (Gerbillus allenbyi and G. pyramidum) reduced their foraging activity, avoiding more profitable open areas and restricting their movements to brushy areas that provided cover (Abramsky et al., 1996). In stream experiments, Scrimgeour et al. (1994a) found that when mayfly larvae were exposed to a model of a fish predator, they increased the amount of time they spent drifting or moved from preferred algae grazing areas on the tops of rocks to the underside of rocks, both responses associated with reduced food intake. In a follow-up study, Scrimgeour and Culp (1994b) found that mayfly responses to perceived predation risk resulted in smaller body size, lower body mass, lower fecundity, and smaller egg size, as earlier reported by Peckarsky (1980); Peckarsky et al., 1993).

\section{Indirect effects of predators on prey demography}

Without experiments, isolating and quantifying the effects antipredator behaviors have on prey demography in the wild is difficult. In particular, if these non-consumptive risk effects (hereafter, risk effects) are not specifically considered by researchers, they are likely to be mistaken for bottom-up effects, i.e. direct offtake is accounted for and any unexplained variability in parameters such as growth rate, pregnancy rates, and survivorship, may be attributed to environmental influences (Creel et al., 2007; Peckarsky et al., 2008). However, several research groups have found compelling evidence that individual prey responses to predation scale up to strongly influence prey demography. In a meta-analysis of 166 studies across diverse taxa, Preisser et al. (2005) found that anti-predator behavior accounted for $63 \%$ of the negative effects carnivores had on prey demography. In field experiments in British Columbia, Zannette et al. (2011) manipulated both real and perceived risk for song sparrows (Mesosiza melodia), using a combination of protective netting and predator call playbacks. Their results were dramatic, with birds exposed to high perceived risk producing $40 \%$ fewer offspring than birds not exposed to the predator call playback. Similar to the mayfly studies above (Scrimgeour et al., 1994a,b), birds exposed to high perceived risk (but no actual predation) paid demographic costs at several stages: they laid fewer eggs, fewer of those eggs hatched, and those that did hatch had lower survival rates due in part to parents making fewer feeding trips to the nest.

\section{Indirect effects of wolves on elk behavior and demography}

In the Rocky Mountain West, many studies have examined how risk effects caused by wolves (Canis lupus) affect elk demography. In a study by Idaho Fish and Game, authored by Zager et al. (2005), researchers compared elk pregnancy rates on two sites, one that had predator numbers substantially reduced, and the other managed for relatively high predator densities, with comparable pregnancy rates prior to manipulation. Following manipulation, the elk pregnancy rate on the reducedpredation risk site was $73 \%$ and the pregnancy rate on the highpredation risk site was $46 \%$.

Creel et al. (2007) sampled fecal progesterone ( $\mathrm{fP}_{4}$, an indicator of pregnancy that showed high correspondence with other indicators including serum pregnancy-specific protein $\mathrm{B}$, and serum progesterone) in multiple elk populations across a broad gradient of predation risk (wolf:elk ratio) and found $\mathrm{fP}_{4}$ levels were negatively correlated with risk, as were the subsequent calf:cow ratios of the herds. These herds were systematically sampled with identical sampling designs, over the same time period (the third trimester of pregnancy) in the same years, for a set of herds in close geographic proximity to one another. By sampling several herds, this study examined responses to a greater scope of variation than can be examined in studies of single sites.

From 1991 to 2007 Garrott et al. (2009) studied a population of $\sim 600$ non-migratory resident elk in the upper Madison drainage in Yellowstone National Park. In 1998, mid-study, wolves colonized the study area. The combination of high wolf use (averaging up to 24 wolves in the study area each day) and a relatively small and declining elk population created high predation risk. Garrott et al. (2009) compared preand post-wolf colonization elk pregnancy rates using serum pregnancy specific protein $\mathrm{B}$ ( $\mathrm{PSPB})$, and serum progesterone and the results were similar to Zager's (2005, above): the authors found that pregnancy rates dropped by approximately $32 \%$ during the latter years of the study (i.e., at the time that wolves became established on the study area). Despite this result, Garrott et al. (2009) argued that predation risk is not related to elk pregnancy rates, and that PSPB, serum progesterone, and $\mathrm{fP}_{4}$ tests all fail (in parallel) for unknown reasons when elk are in high risk environments (see also White et al., 2011, below).

White et al. (2011) compared pre- (1962-1968) and post-wolf reintroduction (2000-2006) pregnancy rates of cow elk on Yellowstone's Northern Range, reporting similar pregnancy rates for the two periods. However a reexamination of the pre-wolf data, including substantial data that White et al. (2011) had omitted for unexplained reasons, revealed that pregnancy rates had indeed fallen from approximately $95 \%$ pre-wolf to $86 \%$ post-wolf (Creel et al., 2011). In addition, important weather variables where not considered, namely that the pre-wolf data were gathered during some of the harshest winters in the last 57 years, while the post-wolf data were gathered during some of the mildest winters in the last 57 years (NRCS data). Moreover, the analysis 
of White et al. (2011) compared body fat measurements for elk herds that were sampled at substantially different times of winter, although it is well established that body condition declines steadily as winter progresses. When seasonal changes in body fat are taken into account, the Yellowstone elk do indeed show reduced fat reserves in comparison to lower predation risk herds elsewhere (Creel et al., 2011).

Middleton et al. (2013a) studied two elk herds, one non-migratory and residing in a largely wolf-free area east of Yellowstone National Park, and the other migratory, spending spring through fall on the eastern edge of the Yellowstone Northern Range, an area of high wolf density. The two herds wintered in overlapping areas. Middleton et al. (2013a) found that the average pregnancy rate for the migratory herd exposed to high wolf predation risk averaged $70.6 \%$, whereas the average pregnancy rate for the relatively wolf-free non-migratory herd was $89.2 \%$ over the same period. In a summary of Middleton's work, Stephenson (2010) illustrated that the pregnancy rate in the migratory herd was slightly but insignificantly increasing prior to wolf reintroduction, but shifted to sharply decreasing the year wolves were reintroduced to Yellowstone in 1995, whereas pregnancy rates in the non-migratory wolf-free herd remained stable. To explain the differences between the two herds, Middleton et al. (2013a) suggested that the effects of climate change abruptly, and coincidentally, began to negatively affect pregnancy rates of the migratory herd (but not the stationary wolf-free herd), the same year that wolves recolonized the area used by the migratory herd. In this study as in many studies of single herd units, collinear changes in several putative drivers of elk dynamics contribute to debate. In such a circumstance, we suggest that the simpler a priori hypothesis of risk effects is better supported than the post-hoc hypothesis of unusually localized and temporally abrupt climate change induced changes in environment, occurring only in the wolf-colonized area.

In a parallel study of the same herds, Middleton et al. (2013b) concluded that elk behavioral responses to the presence of wolves were not sufficient to lead to changes in reproduction. Middleton et al. (2013b) sought to examine real time responses of elk to the presence of wolves at fine time and space scales, correlating elk behavior and habitat use with wolf nearness as determined by GPS collar data from both species. This approach was designed to, “....allow us to compare elk foraging behavior and habitat use before and after wolf encounters." However they did not have wolf location data corresponding with locations for $29 \%$ of the elk for which they had pregnancy data - there were no gps collared wolves near these elk during the study period. Instead of considering these as data points for elk with wolves absent, or simply dropping these points because the independent variable (predation risk) was not measured, the authors instead related elk behavior to wolf gps locations from either the prior or following year, effectively testing whether current elk behavior responds to past or future wolf presence. Thus for a large proportion of the data they did not correlate elk pregnancy rates with concurrent data on elk behavioral responses to wolf presence, their stated goal, and instead tested a hypothesis that, to our knowledge, has not been advanced by anyone. In addition to this, the authors did not account for the effects of unrecorded wolf-elk encounters (i.e., those occurring at times between GPS fixes) that would reduce their ability to detect differences in elk behavior between periods when wolves were present and absent. These unrecorded encounters yielded underestimation of the wolf-elk encounter rate by roughly an order of magnitude (see Creel et al. [2013] for a detailed explanation).

In the same study, Middleton et al. (2013b) compared cow elk body fat between the two aforementioned elk herds. They found that on average, cows in the high risk, low pregnancy rate herd had significantly higher body fat than cow elk in the low-risk, high pregnancy rate herd. Because body fat was higher in the low pregnancy rate herd, the authors concluded that nutritional deficit (as a result of behavioral changes) could not be the reason for the low pregnancy rates. However, given that fewer elk were pregnant in the high risk herd, we would expect mean body fat to be higher as predicted by life history theory - instead of investing energy in offspring, nonpregnant cows were instead investing in their own body condition (Gaillard et al., 1998).

It is important to note that the conclusions reached by Middleton et al. (2013a, b), above) are contradictory. In Middleton et al. (2013a), the authors conclude that changes in the timing and pattern of green up due to climate change are resulting in a lower quality diet for the migratory (high wolf risk) elk herd and that this is the reason for the observed lower pregnancy rates. Whereas in Middleton et al. (2013b), the authors claim that because these same migratory (high wolf risk) elk are on average fatter, their lower pregnancy rate could not be due to nutritional deficit.

Proffitt et al. (2014) compared pre- (1985-1995) and post-wolf reintroduction (1996-2008) elk pregnancy rates on Yellowstone's Northern Range. The authors assessed pregnancy early in the winter, a period when gestation costs are low, so the costs of predator avoidance were unlikely to strongly affect pregnancy rates. Despite this there was a measurable decline in pregnancy rates from the pre- to post-wolf period. However, the authors concluded that since wolves were reintroduced, an increase in average age of cow elk, and a decrease in summer precipitation led to lower pregnancy rates. This is a curious finding given that figure 2B in Proffitt et al. (2014) clearly shows an abrupt drop in elk pregnancy rates beginning 1996, the year after wolves were reintroduced. If 1989, the anomalous year following the extensive Yellowstone fires of 1988, is removed from the figure (fire was not included as an independent variable in the models, thus a priori we know 1988 should not have been included in the analyses), an even clearer picture emerges - an approximately $10 \%$ reduction in Northern Range elk pregnancy rates occurred abruptly when wolves became established on the Northern Range. In addition, wolf-free elk herds elsewhere in the region, subjected to the same climate conditions, do not show a decline in pregnancy rates (e.g. the non-migratory herd in Middleton et al., 2013a, 2013b), and instead were generally increasing or stable (Christianson and Creel, 2014). Thus it is unlikely that regional precipitation changes are responsible for the reduced pregnancy rates documented on Yellowstone's Northern Range. Similarly, it is unlikely that the average age of cows suddenly increased the year wolves were reintroduced and pregnancy rates abruptly declined, 1996 (Proffitt et al., 2014).

In a study of elk calf predation by wolves and bears that spanned 12 populations and included 1999 radio-tagged calves, Griffin et al. (2011) concluded that, "Wolf predation was low and most likely a compensatory source of mortality for neonatal elk calves." This is an important point because several data sets have shown that calf:cow ratios immediately after the birth pulse are negatively correlated with wolf presence, even though these ratios were calculated before significant predation. If wolves are not killing calves and the presence of wolves is correlated with low progesterone concentrations in many herds, then these data align with the hypothesis that the missing calves simply weren't born (Christianson and Creel, 2014).

\section{Trophic cascades}

From the above and other studies, it is clear that carnivores exert considerable pressure on prey populations. In addition to killing prey, populations of carnivores can cause costly changes in prey behavior and diet that scale up to have negative effects on prey demography. Given this, it follows that through their effects on herbivore prey, carnivores could indirectly influence plant community structure. These trophic cascades (Paine, 1980) can potentially be driven by two mechanisms: predator induced changes in prey behavior (behaviorally mediated trophic cascades, BMTC) and; predator caused changes in prey density (density mediated trophic cascades, DMTC); or a combination of both. 


\section{Behaviorally mediated trophic cascades}

Behaviorally mediated trophic cascades are not likely to occur in systems with highly mobile predators and highly mobile prey, because active predators, “... may reduce prey density, but they produce highly variable predation risk cues and are thus unlikely to cause chronic behavioral responses in their prey." (Schmitz, 2008, stress ours). When mobile predators are present, mobile prey behaviorally respond, matching predator moves with complementary countermoves (antipredator behaviors) across the landscape. When the predator leaves an area, mobile prey can reduce their anti-predator responses and feed as they please (e.g. Creel et al., 2005; Winnie and Creel, 2007). Thus plants, particularly favored food, are likely to at best experience only brief (often only hours) respite from herbivory.

Behaviorally mediated trophic cascades (BMTCs) are more likely to occur when prey are faced with sit-and-wait, ambush predators that use at least somewhat predictable habitats types for hunting (Schmitz et al., 2004; Schmitz, 2008). Examples of BMTCs are most common in invertebrate systems wherein herbivore prey such as grasshoppers either avoid places around ambush predators (spiders), or are killed when they attempt graze in these places, leading to local plant release (Schmitz et al., 1997, 2004; Schmitz, 2008). However, if truly risky places can consistently be identified and avoided by prey, we would expect ambush hunting to be strongly selected against and for this mode of hunting to essentially disappear. The fact that ambush hunting has not disappeared indicates that many prey cannot reliably identify and avoid risky places, thus plants are unlikely to be protected by risk prey clearly still use places where they get ambushed and killed by sit and wait predators, and that's what makes these places risky.

A behaviorally mediated trophic cascade involving large vertebrates has been proposed in the Greater Yellowstone Ecosystem. Ripple and Beschta (e.g. Ripple and Beschta, 2004, 2006, 2012; Beschta, 2003, 2005; Beschta and Ripple, 2013a; Beschta et al., 2014), suggest that a BMTC is occurring wherein wolves create permanent patches of high risk on the landscape that elk avoid, in turn releasing woody plants in these patches. However, when the hypothesis is tested with data capable of yielding a negative result, the purported BMTC does not appear to be occurring (Bilyeu et al., 2008; Kauffman et al., 2010; Kimble et al., 2011; Winnie, 2012, 2014). In addition, many of the documented behavioral, spatial, and diet responses that elk have to wolves do not align with the assumptions explicit or inherent in the Yellowstone BMTC hypothesis, as it has been stated. For example, in the absence of elk diet data, proponents of the hypothesis claim that elk decrease their browsing as a response to risk, yet numerous diet studies indicate the opposite, and places with attributes claimed by proponents to be risky (in the absence of risk data), research indicates are not indeed risky (see Winnie, 2012, 2014 for extensive references and a detailed discussion).

In addition to the specific problems with assumptions underpinning the BMTC in Yellowstone hypothesis, there is a more fundamental issue. Twice in recent publications researchers have stated or inferred that one cannot test the BMTC hypothesis unless a BMTC is occurring (Beschta and Ripple, 2013b, Beschta et al., 2014). Thus data from places were a BMTC is not occurring, but the hypothesis predicts one should be occurring, are considered uninformative and excluded from consideration. This approach is not in keeping with the scientific method, nor with accepted practices in hypothesis testing, and illustrates the necessity of revisiting fundamental principles of logic during the design phase of studies. Independent (predictor) variables need to be just that, defined independently of dependent (response) variables. In the case of the above studies, by using dependent variables to define independent variables, the authors could only (and did) achieve one result high correlation between the independent and dependent variables (see Winnie, 2012, 2014 for an extended discussion of this issue).

There are other examples of problematic trophic cascade research. Ripple et al. (2011) proposed two simultaneously acting density mediated wolves-elk-willow-hare-lynx, and wolves-coyotes-harelynx trophic cascades, suggesting that understanding these purported cascades could contribute to lynx (Lynx canadensis) conservation. The paper was criticized by Squires et al. (2012) and Hodges (2012), who pointed out that, as with prior assumptions about wolf effects on elk behavior and diets, empirical data contradicted many aspects of the wolf, elk, coyote (Canis latrans), willow (Salix spp.), and hare (Lepus americanus) interactions assumed by Ripple et al. (2011).

In defending the above proposed cascades, Wirsing et al. (2012) stated, "We conclude by reaffirming our support for opinion pieces in professional journals, whether or not they are buttressed by large amounts of data, as vehicles for new ideas and catalysts for scientific debate and discussion." On the surface this statement is reasonable, but it does little to address specific criticisms. Squires et al. (2012) and Hodges (2012) did not attack the concept of new ideas as catalysts, but instead were specifically critical of Ripple et al.'s (2011) failure to address data that directly describe the basic life histories - diet, behaviors, and distribution - of the animals involved in the purported trophic cascades. In the hypothesized cascades, Ripple et al. (2011) simply got many important details wrong (e.g. diet overlaps between coyote and lynx, and diet overlaps between elk and hares). In addition, Wirsing et al. (2012) did not address the more general point of concern to their critics, namely a tendency to propose new ideas, subsequently treat those ideas as well-tested hypotheses, and then propose that these hypotheses can lead to valuable conservation research and solutions (Squires et al., 2012, Hodges, 2012). The following two examples illustrate these concerns.

Ripple et al. (2014a) proposed another trophic cascade in Yellowstone, wherein wolves reduce elk numbers, which leads to a reduction in browsing of berry bushes, which in turn leads to more berries for grizzly bears (Ursus arctos $h$.) to eat. Thus wolves purportedly indirectly benefit grizzly bears, through effects on elk and berry bushes. This work was criticized by Barber-Meyer (2015) for serious diet and spatial mismatches, and because Ripple et al. (2014a) appear to have ignored in-hand data that contradicted their hypothesis. Based on a sample of 4 (four) post-wolf bear scats, three of which contained berries, Ripple et al. (2014a) concluded that bears increased berries in their diet after wolf reintroduction, despite presenting no pre-wolf bear scat data. They reached this conclusion despite the fact that “... serviceberry was never found in the 778 post-wolf-reintroduction [bear] scats (Fortin et al., 2013, p. 275) they used to demonstrate increased fruit consumption" (Barber-Meyer, 2015). Thus the extensive post-wolf bear scat data Ripple et al. (2014a) had from central Yellowstone indicated no postwolf consumption of service berries by grizzlies, directly contradicting their hypothesis.

Despite the unaddressed problems in Ripple et al. (2014a), later the same year in a different paper, Ripple et al. (2014b) prominently illustrated the above purported trophic cascade in a flow diagram, claiming that wolf-elk-berry bush-bear, “... indirect effects have been shown ..." It is important to reiterate Barber-Meyer's (2015) main points that Ripple et al. (2014a) established no links from wolves to grizzly bears via elk and berry bushes, and that Ripple et al. (2014a) had presented no evidence that grizzlies had increased their consumption of berries in the post-wolf period. Thus the more general concerns of Squires et al. (2012) and Hodges (2012) (above) were manifest again in Ripple et al. (2014b).

\section{Density mediated trophic cascades}

Regardless of complications in the evidence for behaviorally mediated trophic cascades, density mediated trophic cascades (DMTCs) appear to be common, and are well supported by data in both invertebrate and vertebrate systems. DMTCs have been used as tools in agriculture through the introduction of a carnivore to reduce herbivory on domestic crops (e.g. Huffaker and Kennett, 1956), and in freshwater systems to reduce eutrophication by adding a top level 
piscivorous fish to reduce the number of smaller piscivorous fish in the trophic level immediately below it, resulting in herbivore release and decreased algae populations (Shapiro and Wright, 1984).

Perhaps the most widely known, best documented DMTC involving vertebrates is the sea otter-sea urchin-kelp cascade studied by Estes et al. (1978). Otters (Enhydra lutris) were extirpated throughout much of their west coast range by commercial trapping from the mid-19th to early-20th centuries. As a result, populations of sea urchins (Strongylocentrotus spp.), an important food for sea otters, irrupted and decimated kelp (Laminaria spp.) forests. Sea otters became reestablished throughout much of their west coast range by the late 1960s following federal protection. This led to a decline in urchin numbers and an increase in kelp forests (Estes et al., 1978). Note that these responses typify a general pattern in trophic cascades, wherein primary producers benefit from decreased herbivory in trophic cascades with an odd number of levels (e.g. Estes et al., 1978, above), whereas primary producers are limited by increased herbivory in trophic cascades with even numbers of levels (e.g. Shapiro and Wright, 1984, above). In the mid-1990s the sea otter- urchin-kelp system changed again when killer whales (Orcinus orca) began feeding on otters, shifting the system from three to four trophic levels, with the predictable result of sea urchin irruption and kelp decline (Estes et al., 1998). The shift by killer whales to feeding on otters may itself have been driven by a density mediated trophic cascade wherein commercial fishing reduced fish stocks, which led to declines in pinnipeds (the favored food of some killer whale groups), forcing a prey shift to otters by killer whales (Estes et al., 1998).

\section{Effects of density mediated trophic cascades on ecosystem structure}

The effects of density mediated trophic cascades can go well beyond simple prey density changes, and strongly influence local and regional biodiversity. For example, by fixing large amounts of sunlight and carbon, and creating dense three dimensional structure in otherwise vertically limited habitats, kelp provide the foundation for highly diverse communities, but when kelp forests are converted to 2 dimensional barrens by urchins, species diversity declines substantially (Bodkin, 1988; Anderson, 1994; O'Connor and Anderson, 2010).

In addressing patterns of biodiversity Paine $(1966,1969,1980)$ proposed that when carnivores suppress herbivore numbers effectively, competitively superior herbivore species (e.g. sea urchins) cannot numerically overrun their own trophic level, and this in turn limits their effects on plant biomass and plant community and ecosystem structure. The strength of herbivore suppression by carnivores is well illustrated in the literature with examples of herbivore irruptions when released from top-down pressure. Leopold et al. (1947) examined the causes and effects of 96 deer irruptions across 28 States in the midst of aggressive federal and state predator reduction programs in the U.S. In most cases, irruptions were coincident with local predator eradication, and as a result of the increased deer populations, habitat degradation or increased crop damage often occurred. Following irruptions, many deer populations crashed due to winter starvation. In addition to this, and despite often aggressive human interventions that included the killing of female deer, habitat degradation and boom-bust cycles were repeated (Leopold et al., 1947).

When reindeer (Rangifer tarandus) were released from predation pressure by being introduced to predator-free St. Matthew, St. George and St. Paul Islands in the Alaskan Pribiloffs their populations grew exponentially to high densities then crashed dramatically in response to a combination of hard winters and degraded food resources (Scheffer, 1951; Klein, 1968). While small island dynamics may be more dramatic than those taking place over larger areas, similar irruptive cycles have been observed in more open systems e.g. Leopold et al. (1947) above, non-native introductions in New Zealand (Caughley, 1970), and elk in Yellowstone National Park after management transitioned to natural regulation (no culling of elk) in 1969, but before wolves were reintroduced in 1995 (NPS data).

In a series of dramatic pseudo experiments Terborgh et al. (2001) investigated tropical forest community structure on newly created islands in a Venezuelan reservoir. Islands ranged in size from 0.25 to $>150$ ha, and once isolated, all islands lost predators with resulting explosions in herbivore populations. Herbivore densities increased from 20 to over 100 times their densities on nearby mainland and the effects on plant communities were profound. Tree recruitment fell by $50 \%$ or more, plant density declined and there were radical shifts in both plant and animal community composition, leading the authors to describe the results as, "ecological distortions" (Terborgh et al., 1997). In essence, once removed from top-down constraints, the herbivores on these islands began behaving like invasive species, with dominant competitors' populations exploding, leading to substantial habitat degradation, local extirpation of competitors and overall lower biodiversity when compared to nearby mainland sites.

\section{Conclusion}

Whether or not herbivores behave like invasive species depends on their ecological context, and in systems without substantial bottom-up control, that context is strongly constrained by their predators. Evidence across multiple taxa and systems shows that the efficiency with which predators suppress prey numbers is quite high, considerably higher than assumed in traditional predator-prey ecology wherein direct offtake is assumed to be the only influence of carnivores on prey demography (Lotka, 1925). This tremendous top-down pressure is due to the combination of direct effects (consumption), and indirect risk effects (prey behavior and diet changes in response to the threat of predation that in turn lead to lower fecundity) and helps explain why herbivore demographic responses to release can be so dramatic. When carnivores are extirpated, even native herbivores often behave like invasive species, and the resulting changes in ecosystems are virtually indistinguishable from non-native herbivore introductions into predator-free environments. Both frequently result in irruption of the herbivore population, subsequent plant biomass reduction, range degradation, and substantial changes in plant and animal community structure (Leopold et al., 1947; Paine, 1966, 1969; Klein, 1968; Menge and Sutherland, 1976; Terborgh et al., 1997, 2001; Pinnegar et al., 2000; Miller et al., 2001; Estes et al., 2011). Thus regardless of their roles in healthy, intact ecosystems, native herbivores can essentially become invasive, weedy species causing substantial ecosystem disruption when released from the powerful top-down pressures of carnivores.

\section{References}

Abramsky, Z., Strauss, E., Subach, A., Riechman, A., Kotler, B.P., 1996. The effect of barn owls (Tyto alba) on the activity and microhabitat selection of Gerbillus allenbyi and G. pyramidum. Oecologia 105 (3), 313-319.

Altweg, R., 2002. Predator-induced life-history plasticity under time constraints in pool frogs. Ecology 83 (9), 2542-2551.

Anderson, T.W., 1994. Role of macroalgal structure in the distribution and abundance of a temperate reef fish. Mar. Ecol. Prog. Ser. 113, 279-290.

Bachman, G.C., 1993. The effect of body condition of the tradeoff between vigilance and foraging in Belding's ground squirrels. Anim. Behav. 46, 233-244.

Barber-Meyer, S.M., 2015. Trophic cascades from wolves to grizzly bears or changing abundance of bears and alternate foods? J. Anim. Ecol. 84 (3), 647-651.

Bengtson, S., 2002. Origins and early evolution of predation. Paleontol. Soc. Pap. 8, 289-317.

Bertram, B.C., 1980. Vigilance and group size in ostriches. Anim. Behav. 28 (1), 278-286. Berven, K.A., Gill, D.E., 1983. Interpreting geographic variation in life-history traits. Am. Zool. 23, 85-97.

Beschta, R.L., 2003. Cottonwoods, elk, and wolves in the Lamar Valley of Yellowstone National Park. Ecol. Appl. 13, 1295-1309.

Beschta, R.L., 2005. Reduced cottonwood recruitment following the extirpation of wolves in Yellowstone's Northern Range. Ecology 86, 391-403.

Beschta, R.L., Ripple, W.J., 2013a. Are wolves saving Yellowstone's aspen? A landscapelevel test of a behaviorally mediated trophic cascade: comment. Ecology 94, $1420-1425$ 
Beschta, R.L., Ripple, W.J., 2013b. Are wolves saving Yellowstone's aspen? A landscapelevel test of a behaviorally mediated trophic cascade: comment. Ecology 94, $1420-1425$.

Beschta, R.L., Eisenberg, C., Laundré, J.W., Ripple, W.J., Rooney, T.P., 2014. Predation risk, elk, and aspen: comment. Ecology 95, 2669-2671.

Bilyeu, D.M., Cooper, D.J., Hobbs, N.T., 2008. Water tables constrain height recovery of willow on Yellowstone's Northern Range. Ecol. Appl. 18, 80-92.

Bodkin, J.L., 1988. Effects of kelp forest removal on associated fish assemblages in Central California. J. Exp. Mar. Biol. Ecol. 117, 227-238.

Caughley, G., 1970. Eruption of ungulate populations, with emphasis on Himalayan thar in New Zealand. Ecology 53-72.

Christianson, D., Creel, S., 2008. Risk effects in elk: sex-specific response in grazing and browsing due to predation risk from wolves. Behav. Ecol. 19, 1258-1266.

Christianson, D., Creel, S., 2014. Ecosystem scale declines in elk recruitment and population growth with wolf colonization: a before-after-control-impact approach. PLoS One 7, 1-12 (July 9).

Creel, S., Winnie Jr., J., Maxwell, B., Hamlin, K., Creel, M., 2005. Elk alter habitat selection as an antipredator response to wolves. Ecology 86 (12), 3387-3397.

Creel, S., Christianson, D., Liley, S., Winnie Jr., J., 2007. Predation risk affects reproductive physiology and demography of elk. Science 315, 960.

Creel, S., Christianson, D.A., Winnie Jr., J., 2011. A survey of the effects of wolf predation risk on pregnancy rates and calf recruitment in elk. Ecol. Appl. 21, 2847-2853.

Creel, S., Winnie, J.A., Christianson, D., 2013. Underestimating the frequency, strength and cost of anti-predator responses with data from GPS collars: an example with wolves and elk. Ecol. Evol. 3, 5189-5200.

Creel, S., Schuette, P., Christianson, D., 2014. Effects of predation risk on group size, vigilance and foraging behavior in an African ungulate community. Behav. Ecol. 25 (4), $773-784$.

Erwin, D.H., Laflamme, M., Tweedt, S.M., Sperling, E.A., Pisani, D., Peterson, K.J., 2011. The Cambrian conundrum: early divergence and later ecological success in the early history of animals. Science 334 (6059), 1091-1097.

Estes, J.E., Smith, N.S., Palmisano, J.F., 1978. Sea otter predation and community organization in the western Aleutian Islands, Alaska. Ecology 822-833.

Estes, J.A., Tinker, M.T., Williams, T.M., Doak, D.F., 1998. Killer whale predation on sea otters linking oceanic and nearshore ecosystems. Science 282 (5388), 473-476.

Estes, J.A., Terborgh, J., Brashares, J.S., Power, M.E., Berger, J., Bond, W.J., ... Wardle, D.A., 2011. Trophic downgrading of planet Earth. Science 333 (6040), 301-306

Fortin, J.K., Schwartz, C.C., Gunther, K.A., Teisberg, J.E., Haroldson, M.A., Robbins, C.T., 2013. Dietary adjustability of grizzly bears and American black bears in Yellowstone National Park. J. Wildl. Manag. 77, 270-281.

Gaillard, J.-M., Festa-Bianchet, M., Yoccoz, N.G., 1998. Population dynamics of large herbivores: variable recruitment with constant adult survival. Trends Ecol. Evol. 13, 58-63.

Garrott, R., White, P.J., Rotella, J., 2009. The Madison headwaters elk herd: transitioning from bottom up regulation to top down limitation. In: Garrott, R., White, P. Watson, F.G.R. (Eds.), The Ecology of Large Mammals in Central Yellowstone. Elsevier, San Diego, California, USA, pp. 489-517.

Griffin, K., Hebblewhite, M., Robinson, H., Zager, P., Barber-Meyer, S.M., Christianson, D. Creel, S., Harris, N., Hurley, M., Jackson, D., 2011. Neonatal mortality of elk driven by climate, predator phenology and predator diversity. J. Anim. Ecol. 80, 1246-1257.

Heithaus, M.R., Dill, L.M., 2002. Food availability and tiger shark predation risk influence bottlenose dolphin habitat use. Ecology 83, 480-491.

Hodges, K.E., 2012. Data-free speculation does not make for testable hypotheses: a reply to ripple et al. Wildl. Soc. Bull. 36, 561-566.

Huffaker, C.B., Kennett, C.E., 1956. Experimental studies on predation: predation and cyclamen mite predation on strawberries in California. Hilgardia 26, 191-222.

Jennings, T., Evans, S.M., 1980. Influence of position in the flock and flock size on vigilance in the starling, Sturnus vulgaris. Anim. Behav. 28 (2), 634-635.

Kauffman, M., Brodie, J.F., Jules, E.S., 2010. Are wolves saving Yellowstone's aspen? A landscape-level test of a behaviorally mediated trophic cascade. Ecology 91, 2742-2755.

Kimble, D.S., Tyers, D.B., Robinson-Cox, J., Sowell, B.F., 2011. Aspen recovery since wolf reintroduction on the Northern Yellowstone winter range. Rangel. Ecol. Manag. 64 (2), 119-130.

Klein, D.R., 1968. The introduction, increase, and crash of reindeer on St. Matthew Island. J. Wildl. Manag. 350-367.

Leopold, A., Sowls, L.K., Spencer, D.L., 1947. A survey of over-populated deer ranges in the United States. J. Wildl. Manag. 162-177.

Lotka, A.J., 1925. Elements of Physical Biology. Williams and Wilkins Company.

Menge, B.A., Sutherland, J.P., 1976. Species diversity gradients: synthesis of the roles of predation, competition, and temporal heterogeneity. Am. Nat. 351-369.

Middleton, A.D., Kauffman, M.J., McWhirter, D.E., Cook, J.G., Cook, R.C., Nelson, A.A., 2013a. Animal migration amid shifting patterns of phenology and predation: lessons from a Yellowstone elk herd. Ecology 94, 1245-1256.

Middleton, A.D., Kauffman, M.J., McWhirter, D.E., Jimenez, M.D., Cook, R.C., Cook, J.G., 2013b. Linking anti predator behaviour to prey demography reveals limited risk effects of an actively hunting large carnivore. Ecol. Lett. 16, 1023-1030.

Miller, B., Dugelby, B., Foreman, D., del Rio, C.M., Noss, R., Phillips, M., ... Willcox, L., 2001. The importance of large carnivores to healthy ecosystems. Endanger. Species Updat. 18 (5), 202-210.

O'Connor, K.C., Anderson, T.W., 2010. Consequences of habitat disturbance and recovery to the recruitment and abundance of kelp forest fishes. J. Exp. Mar. Biol. Ecol. 386 $1-10$

Paine, R.T., 1966. Food web complexity and species diversity. Am. Nat. 65-75.
Paine, R.T., 1969. The Pisaster-Tegula interaction: prey patches, predator food preference, and intertidal community structure. Ecology 950-961.

Paine, R.T., 1980. Food webs: linkage, interaction strength and community infrastructure J. Anim. Ecol. 667-685.

Peckarsky, B.L., 1980. Predator-prey interactions between stoneflies and mayflies: behavioral observations. Ecology 1980, 932-943.

Peckarsky, B.L., Cowan, C.A., Penton, M.A., Anderson, C., 1993. Sublethal consequences of stream-dwelling predatory stoneflies on mayfly growth and fecundity. Ecology 74 (6), 1836-1846.

Peckarsky, B.L., Abrams, P.A., Bolnick, D.I., Dill, L.M., Grabowski, J.H., Luttbeg, B., ... Trussell, G.C., 2008. Revisiting the classics: considering nonconsumptive effects in textbook examples of predator-prey interactions. Ecology 89 (9), 2416-2425.

Pinnegar, J.K., Polunin, N.V.C., Francour, P., Badalamenti, F., Chemello, R., Harmelin-Vivien, M.L., ... Pipitone, C., 2000. Trophic cascades in benthic marine ecosystems: lessons for fisheries and protected-area management. Environ. Conserv. 27 (02), 179-200.

Preisser, E.L., Bolnick, D.I., Benard, M.F., 2005. Scared to death? The effects of intimidation and consumption in predator-prey interactions. Ecology 86 (2), 501-509.

Proffitt, K.M., Cunningham, J.A., Hamlin, K.L., Garrott, R.A., 2014. Bottom-up and top-down influences on pregnancy rates and recruitment of northern Yellowstone elk. J. Wildl. Manag. 78 (8), 1383-1393.

Ripple, W.J., Beschta, R.L., 2004. Wolves, elk, willows and trophic cascades in the upper Gallatin Range of southwestern Montana, USA. For. Ecol. Manag. 200, $161-181$

Ripple, W.J., Beschta, R.L., 2006. Linking wolves to willows via risk-sensitive foraging by ungulates in the Northern Yellowstone Ecosystem. For. Ecol. Manag. 230, 96-106.

Ripple, W.J., Beschta, R.L., 2012. Trophic cascades in Yellowstone: the first 15 years after wolf reintroduction. Biol. Conserv. 145 (1), 205-213.

Ripple, W.J., Wirsing, A.J., Beschta, R.L., Buskirk, S.W., 2011. Can restoring wolves aid in lynx recovery? Wildl. Soc. Bull. 35, 514-518.

Ripple, W.J., Beschta, R.L., Fortin, J.K., Robbins, C.T., 2014a. Trophic cascades from wolves to grizzly bears in Yellowstone. J. Anim. Ecol. 83 (1), 223-233.

Ripple, W.J., Estes, J.A., Beschta, R.L., Wilmers, C.C., Ritchie, E.G., Hebblewhite, M., ... Wirsing, A.J., 2014b. Status and ecological effects of the world's largest carnivores. Science 343 (6167), 1241484.

Scheffer, V.B., 1951. The rise and fall of a reindeer herd. Sci. Mon. 73, 356-362.

Schmitz, O., 2008. Effects of predator hunting mode on grassland ecosystem function. Science 319,952

Schmitz, O.J., Beckerman, A.P., O'Brien, K.M., 1997. Behaviorally-mediated trophic cascades: the effects of predation risk on food web interactions. Ecology 78 , 1388-1399.

Schmitz, O.J., Krivan, V., Ovadia, O., 2004. Trophic cascades: the primacy of trait-mediated indirect interactions. Ecol. Lett. 7, 153-163.

Scrimgeour, G.J., Culp, J.M., 1994b. Feeding while evading predators by a lotic mayfly: linking short-term foraging behaviours to long term fitness consequences. Oecologia $100,128-134$

Scrimgeour, G.J., Culp, J.M., Cash, K.C., 1994a. Anti-predator responses of mayfly larvae to conspecific and predator stimuli. J. Am. Benthol. Soc. 13, 299-309.

Semlitsch, R.D., 1985. Reproductive strategy of a facultatively aedomorphic salamander Ambystoma talpoideum. Oecologia (Berlin) 65, 305-313.

Semlitsch, R.D., Scott, D.E., Pechmann, J.H.K., 1988. Time and size at metamorphosis related to adult fitness in Ambystoma talpoideum. Ecology 69, 184-192.

Shapiro, J., Wright, D.I., 1984. Lake restoration by biomanipulation. Freshw. Biol. 14 371-383.

Skelly, D.K., Werner, E.E., 1990. Behavioral and life-historical responses of larval American toads to an Odonate predator. Ecology 23, 13-2322 (71:6 1990).

Sperling, E.A., Frieder, C.A., Raman, A.V., Girguis, P.R., Levin, L.A., Knoll, A.H., 2013. Oxygen, ecology, and the Cambrian radiation of animals. PNAS 110 (33), 13446-13451.

Squires, J.R., Decesare, N.J., Hebblewhite, M., Berger, J., 2012. Missing lynx and trophic cascades in food webs: a reply to ripple et al. Wildl. Soc. Bull. 36, 567-571.

Stephenson, S., 2010. Hunting for Answers. Wyoming Wildlife. Publication of the Wyoming Department of Fish and Game, pp. 2-11 (11/2010).

Terborgh, J., Lopez, L., Tello, J., Yu, D., Bruni, A.R., Laurence, W.L., 1997. Transitory states in relaxing ecosystems of land bridge islands. In: Bierregaard Jr., R.O. (Ed.), Tropical Forest Remnants, pp. 256-274.

Terborgh, J., Lopez, L., Nunez, P., Rao, M., Shahabuddin, G., Orihuela, G., ... Balbas, L., 2001 Ecological meltdown in predator-free forest fragments. Science 294 (5548), 1923-1926.

Thaker, M., Vanak, A.T., Owen, C.R., Ogden, M.B., Niemann, S.M., Slotow, R., 2011. Minimizing predation risk in a landscape of multiple predators: effects on the spatial distribution of African ungulates. Ecology 92 (2), 398-407.

Underwood, R., 1982. Vigilance behaviour in grazing African antelopes. Behaviour 79 (2) 81-107.

Wells, K.D., 1977. Territoriality and mating success in the green frog (Rana clamitans) Ecology 58, 750-762.

Werner, E.E., Gilliam, J.F., Hall, D.J., Mittelbach, G.G., 1983. An experimental test of the effects of predation risk on habitat use in fish. Ecology 64, 1540-1548.

White, P.J., Garrott, R.A., Hamlin, K.L., Cook, R.C., Cook, J.G., Cunningham, J.A., 2011. Body condition and pregnancy in northern Yellowstone elk: evidence for predation risk effects? Ecol. Appl. 21, 3-8.

Winnie Jr., J., 2012. Predation risk, elk, and aspen: tests of a behaviorally mediated trophic cascade in the Greater Yellowstone ecosystem. Ecology 93 (12), 2600-2614.

Winnie Jr., J., 2014. Predation risk, elk, and aspen: reply. Ecology 95 (9), 2671-2674 (2014).

Winnie Jr., J., Creel, S., 2007. Sex-specific behavioural response to spatial and temporal variation in the threat of wolf predation. Anim. Behav. 73, 215-225. 
Wirsing, A.J., Buskirk, S.W., Ripple, W.J., Beschta, R.L., 2012. Wolves and lynx: plausible ideas make for testable hypotheses. Wildl. Soc. Bull. 36 (3), 572-577.

Zager, P., White, C., Pauley, G., 2005. Elk ecology: factors influencing elk calf recruitment. Project W-160-R-32, Subproject 31. Idaho Department of Fish and Game, Boise, Idaho, USA.
Zannette, L.Y., White, A.F., Allen, M.C., Clinchy, M., 2011. Perceived predation risk reduces the number of offspring songbirds produce per year. Science 334, 1398-1401. 